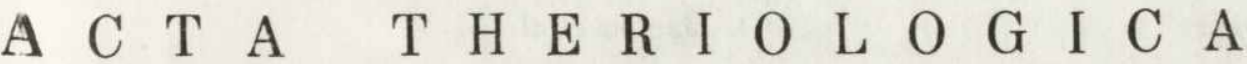

VOL. XIII, 16: 285-294.

BIAŁOWIEŻA

$30 . \mathrm{X} .1968$

Mirosław JANION, Lech RYSZKOWSKI \& Teresa WIERZBOWSKA

\section{Estimate of Number of Rodents with Variable Probability of Capture*)}

[With 4 Figs \& 4 Tables]

\begin{abstract}
The objective of the study was to elaborate a method of calculations which would permit of estimating the numbers of rodents in cases when the variations in the number of individuals caught on successive days of trapping make it impossible to apply the linear regression method. When estimating the number of individuals present during trapping and removal the conditional distribution of variable $X$ (4) was accepted. The mean value of this distribution was calculated from equation (6) and the number of individuals present in the study area during a period od $k$ days was estimated by means of formula (8). The proposed method for estimating the number of rodents can also be applied when catching rodents in live traps. The proposed method for estimating numbers frees the research of the limitations imposed by Hayne's method (the likelihood of catching all the rodents present is uniform, there are no variations in the numbers of rodents during the trapping period) and is analogical to the proposal made by $\mathrm{M}$ or a $\mathrm{n}$ in 1951 and $\mathrm{Zippin}$ in 1956. Its application is facilitated by the use of tables (1 and 2) making rapid calculation of the required estimate of numbers of rodents possible. The proposed method of calculations also permits of estimating likelihood of capture during different periods of trapping operations.
\end{abstract}

\section{INTRODUCTION, STUDY AREA AND METHOD}

The aim of the study was to elaborate a method of calculations permitting of estimating the numbers of rodents when the variations in the number of individuals caught on successive trapping days make it impossible to apply the method of linear regression.

Captures of rodents were made in the Kampinos Forest near the Field Station of the Institute of Ecology, Polish Academy of Sciences, at Dziekanów Leśny near Warsaw in the summer 1967 . The study area $(4.41 \mathrm{ha})$ was covered by a forest which formed a mosaic of the following associations: Pineto-Quercetum, Vaccinio

* This study was carried out under the Small Mammal Project of the International Biological Programme in Poland. 
myrtilli-Pinetum, Tilio-Carpinetum, Carici elongatae-Alnetum ( $\mathrm{Traczyk}$ \& $\mathrm{Traczyk}$, 1965). Among the species of rodents caught the most numerously

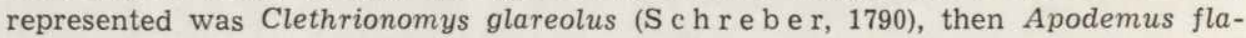
vicollis (M elchior, 1834), and least frequently A. agrarius (P a 11 a s, 1771).

Captures of small rodents were made by means of live-traps placed at the intersections of ten rows and ten lines perpendicular to them. The distance between rows and lines was $15 \mathrm{~m}$. Oats were used as bait. The traps were inspected twice daily - morning and evening. Two series of captures were carried out, each series consisting of two phases. In the first phase the animals caught were individually marked, recorded and released on the capture site. In the second phase all the animals caught were removed from the place of capture. In the first series of captures the mark-release period lasted four days, and the capture and removal period five days. In the second series of captures both phases lasted five days each.

\section{METHOD OF CALCULATIONS}

H a y n e (1949) proposed a method which consists of comparing the number of individuals caught each day, plotted against cumulative numbers of individuals previously caught. The number of animals caught on a given day is set out on the axis of ordinates, and the cumulated number of animals caught up to a given day on the abscissae axis. By calculating for the the above data the equation of linear regression it is possible to calculate the point of intersection of linear regression with the axis of abscissae, which forms the estimate of population numbers in the study area. The correctness of estimate depends on the following premises: (1) All the individuals in the population have a uniform chance of being caught, (2) There is either no or very little change of population size during the sampling period, (3) Capture conditions are similar throughout the whole sampling period. If the above-mentioned premises are violated then the estimates of population size obtained by that method are wrong.

In order correctly to assess the number of animals it is necessary in this case to make calculations based on a principle different from that used when applying linear regression.

As the result of animals entering the area or their varying probability of capture on successive days, we find that the number of animals revealing their presence in the area differs from that anticipated when constant probability of capture is assumed. The number of all animals in the study area during a given period is given the symbol $N$, including in this number the individuals which entered the area during captures. We next indicate by the letter $p$ the mean probability of capture for the whole capture period, which is the mean value of different probabilities of capture on different days. The distribution of number of days from the time of setting up the traps 
to the individuals revealing their presence in the area is a geometrical distribution with the following form:

$$
P_{1, k}(x=t)=p \cdot q^{t} \quad \text { for } t=0,12 \ldots \ldots \infty
$$

with a mean

$$
E_{o, \infty}(x)=\frac{q}{p} \ldots \ldots
$$

where $1-p=q$

The period in which 99 per cent individuals (from $N$ individuals which are present during days of trapping) manifest their presence is:

$$
\tau=\frac{-4.60517}{\ln q}-1=\frac{4.60517}{\ln \frac{1}{q}}-1 \ldots \ldots
$$

Formula (1) cannot be used when assessing the number of individuals present during capture and removal as the trapping period is limited and usually lasts a few days only. It is therefore necessary to accept the conditional distribution of variable $X$ with the following form:

$$
P_{1, k}(X=t)=P_{1, k}(X=t \mid 0 \leqslant t \leqslant k-1)=\frac{P_{1, \infty}(X=t)}{\sum_{t=0}^{k-1} P_{1}, \infty(X=t)}
$$

where $k$ - number of capture days

After conversion we obtain:

$$
P_{1, k}(X=t)=\frac{p q^{t}}{1-q^{k}} \cdots \cdots
$$

for $t=0,1,2 \ldots \ldots k-1$ days

We calculate the mean value of this distribution from the equation:

$$
E_{1, k}(X)=\frac{q}{p}-\frac{k q^{k}}{1-q^{k}} \ldots \ldots
$$

If $N_{1, k}$ indicates the sum total of all individuals caught during the first $k$ days of capture and removal:

$$
N_{1, k}=\sum_{i=1}^{k} y_{i} \ldots \ldots
$$

where $y_{i}$ - number of individuals caught in day $i$, then we can estimate the number of individuals staying in the study area $(N)$ for a period of $k$ days by means of the formula

$$
N=\frac{N_{1, k}}{1-q^{k}} \ldots \ldots
$$

where $q$ is calculated from formula (6) accepting as $E_{1, k}(X)$ - the empirically obtained mean number of days from time of setting up the traps to manifestation of their presence by the individuals caught 


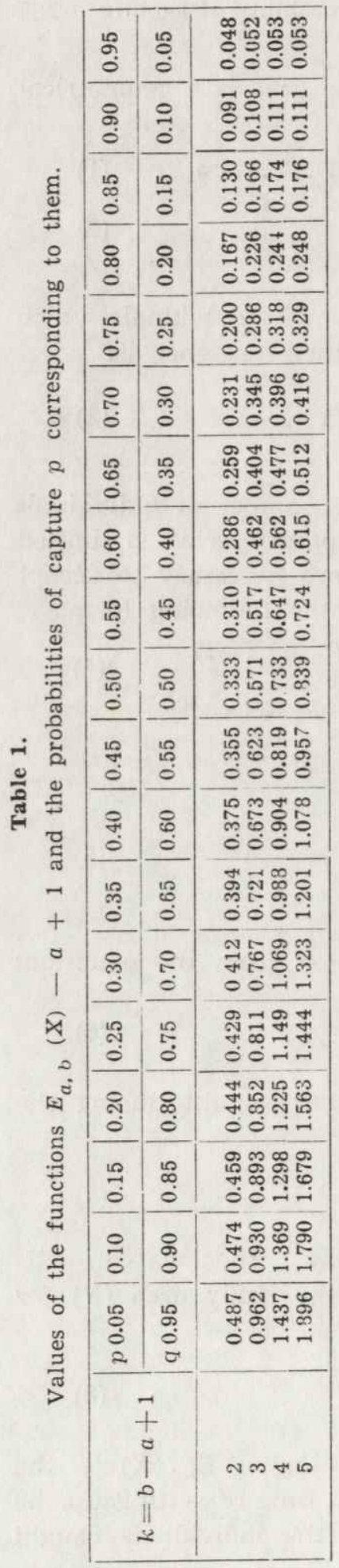

\begin{tabular}{|c|c|c|c|c|c|}
\hline 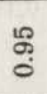 & $\stackrel{\text { In }}{0}$ & 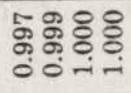 & 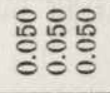 & 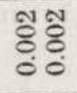 & $\begin{array}{l}8 \\
\delta \\
0\end{array}$ \\
\hline $\begin{array}{l}\text { \& } \\
\circ\end{array}$ & $\stackrel{0}{\circ}$ & 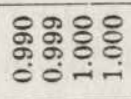 & 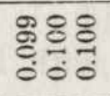 & $\begin{array}{l}0 \\
0 \\
0 \\
0\end{array}$ & 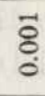 \\
\hline $\begin{array}{l}10 \\
\stackrel{\infty}{0} \\
0\end{array}$ & $\frac{10}{0}$ & 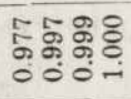 & 녕 & $\begin{array}{l}\text { ฟै ลี } \\
\text { ¿ें } \\
0\end{array}$ & ஜ̊ \\
\hline$\stackrel{\circ}{\circ}$ & ڤ્ & 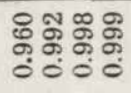 & 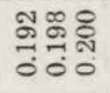 & $\begin{array}{l}\infty 00 \\
00 \\
0 \\
0 \\
0\end{array}$ & $\stackrel{\infty}{8}$ \\
\hline & $\stackrel{\stackrel{\circ}{\sim}}{\circ}$ & 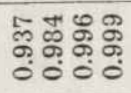 & 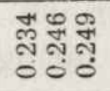 & 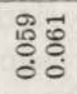 & $\frac{10}{0}$ \\
\hline$\underset{0}{0}$ & 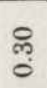 & 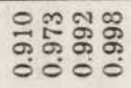 & 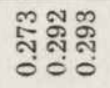 & 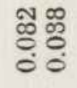 & 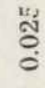 \\
\hline $\begin{array}{l}10 \\
0 \\
0\end{array}$ & $\begin{array}{l}\text { एొ } \\
\text { ֻे }\end{array}$ & 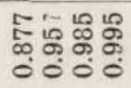 & 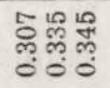 & 占告 & 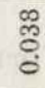 \\
\hline$\stackrel{8}{8}$ & $\stackrel{0}{\circ}$ & 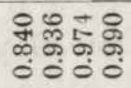 & 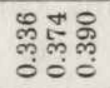 & 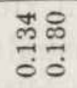 & 蒄 \\
\hline 占 & $\stackrel{10}{+0}$ & 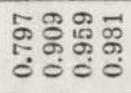 & 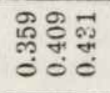 & 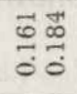 & $\stackrel{2}{5}$ \\
\hline $\begin{array}{l}\stackrel{10}{0} \\
0\end{array}$ & $\begin{array}{l}\text { i⿱ } \\
\text { ț }\end{array}$ & 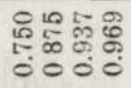 & 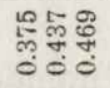 & 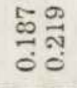 & 苛 \\
\hline$\stackrel{10}{\stackrel{\circ}{\circ}}$ & 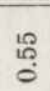 & 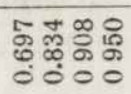 & 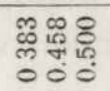 & 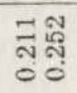 & $\stackrel{\oplus}{\ddot{\theta}}$ \\
\hline$\stackrel{\circ}{\circ}$ & $\stackrel{8}{0}$ & 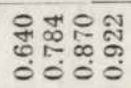 & 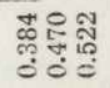 & 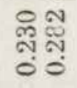 & $\stackrel{\infty}{\stackrel{\infty}{0}}$ \\
\hline ભొ & $\stackrel{\mathscr{0}}{\mathscr{0}}$ & 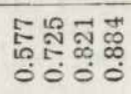 & 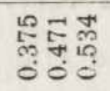 & 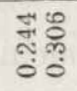 & $\frac{10}{0}$ \\
\hline 尺्ల్ & $\begin{array}{l}\circ \\
0 \\
0\end{array}$ & 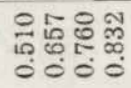 & 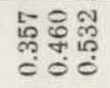 & 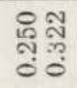 & $\frac{10}{0}$ \\
\hline ֻั & $\stackrel{10}{5}$ & 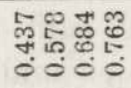 & 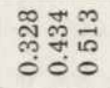 & 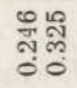 & $\stackrel{10}{\frac{10}{0}}$ \\
\hline$\stackrel{\text { กิ }}{\text { }}$ & $\begin{array}{l}8 \\
\infty \\
0\end{array}$ & 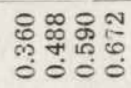 & 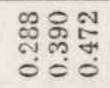 & 节 & $\begin{array}{l}\vec{\infty} \\
\overrightarrow{0}\end{array}$ \\
\hline$\stackrel{\circ}{\circ}$ & $\begin{array}{l}10 \\
\infty \\
0\end{array}$ & 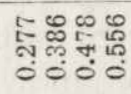 & 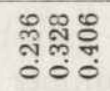 & 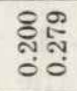 & $\stackrel{0}{0}$ \\
\hline$\stackrel{0}{\circ}$ & \& & 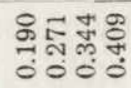 & $\begin{array}{l}\text { 평 } \\
\text { ப் ஸ் }\end{array}$ & 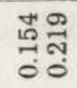 & $\begin{array}{l}\infty \\
\stackrel{m}{-1} \\
0\end{array}$ \\
\hline $\begin{array}{l}\text { Lo } \\
0 \\
0 \\
2\end{array}$ & $\begin{array}{l}\text { 。̊ } \\
\text { ᄋ } \\
0\end{array}$ & 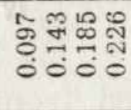 & 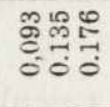 & $\begin{array}{l}\infty \\
\stackrel{2}{0} \\
0 \\
0 \\
0\end{array}$ & 范 \\
\hline \multicolumn{2}{|c|}{0} & Nmナட & ल & 小ட & 10 \\
\hline \multicolumn{2}{|c|}{$\approx$} & -1 & N & $\infty$ & + \\
\hline
\end{tabular}


during this period. In order to simplify calculations we have given in the form of table 1 which values of $p$, and thus also of $q$, correspond to defined values $k$ and empirically calculated values of the mean period of manifestation of presence $E_{1, k}(X)$. In cases when the $E_{1, k}(X)$ values come between the $p$ values given in table 1 we use linear interpolation. The procedure is the same when using table 2 . For instance, during five days of capture and removal in the second trapping series (Fig. 3B) the following numbers of all rodents were caught in consecutive days: $28,20,18,25$ and 10 . Hence

$$
E_{1,5}(X)=\frac{0 \cdot 28+1 \cdot 20+2 \cdot 18+3 \cdot 25+4 \cdot 10}{101}=1.69
$$

On the basis of the value found $E_{1,5}(X)=1.69$ and $k=5$ days of capture and removal, we find from table 1 that $p=0.15$ and $q=0.85$. In order to estimate the number of all individuals present during this period by means of formula (6) it is necessary to calculate the value of the expression $1-q^{k}$. This value is $\left(1-q^{k}\right)=0.5563$ (Table 2). We next estimate the number of individuals on the basis of formula (8).

The method proposed in this study for estimating the number of rodents can also be applied in the case of captures of rodents in live-traps, as these individuals are marked and released on the capture site. The mean period of manifestation of their presence $E_{1, k}(X)$ is calculated, as in the case of capture and removal of rodents, taking only the first captures of individuals for analysis.

Application of the conditional distributions makes it possible to demonstrate variations in trappability during the course of trapping. For instance the estimate of mean probability of capture and removal $p$ obtained from the first three days should not differ from estimate $p$ obtained from the last three captures when no additional animals enter the area nor changes take place in their trappability. As an example, captures lasted $k$ days, but material was taken for calculations only from day $a$ to day $b$, where $a=1,2 . k-1$, whereas $b=a+1, a+2$, $a+3 \ldots k$ days. The conditional distribution of number of days after which individuals reveal their presence then takes the following form:

thus

$$
P_{a, b}(X=t)=\frac{P_{1}, \infty(X=t)}{\sum_{t=a-1}^{b-1} P_{1}, \infty(X=t)} \ldots \ldots
$$

$$
P_{a, b}(X=t)=\frac{p q^{t}}{q^{a-1}\left(1-q^{b-a+1}\right)} \cdots \cdots
$$


where $t=a-1, a, \ldots b-1$

$b=a+1, a+2 \ldots k$

with the mean value

$$
E_{a, b}(X)=\frac{q}{p}+(a-1)-\frac{(b-a+1)}{1-q^{b-a+1}} q^{b-a+1} \ldots \ldots
$$

where $a=1,2, \ldots \ldots \ldots k-1$

$b=a+1 \ldots \ldots k$

If we indicate by $N_{a, b}$ the sum total of all individuals caught during the period from day $a$ to day $b$, then we can estimate the number of individuals present during the whole period by means of the formula

$$
N=\frac{N_{a, b}}{q^{a-1} \quad\left(1-q^{b-a+1}\right)} \cdots \cdots
$$

where $q$ is calculated from formula (11). Values $p$, and thus also values $q$ depending on $a$ and $b$ and the empirically calculated values $E_{a, b}(X)$ $-a+1$, are given in table 1 . The values of the expression $q^{a-1}(1-$ $q^{b-a+1}$ ) depending on $a$ and $b$ and $q$ are given in table 2. This table can also be used for calculations of the value of the expression $1-q^{k}$ occurring in the denominator of formula (8). In this case $a=1, b=k$.

\section{RESULTS}

Calculations were made for all species of rodents treated jointly, and separately for the species occurring most numerously in the study area, C. glareolus. During the phase of marking and releasing the animals caught in the first series of captures a number of animals caught for the first time was obtained which increased in succeeding days (Fig. 1A, Fig. 2A). During the phase of capture and removal of this trapping series we obtained a number of rodents decreasing in succeeding days, with the exception of the fifth day, where there was a slight increase in the number of rodents in relation to the fourth day (Fig. 1B). A continuous decrease in the number of animals caught in succeeding days was observed in the case of C. glareolus (Fig. 2B).

In the second series of captures the reverse phenomenoon was recorded. During the phase of marking and release on the capture site a continuous decrease was observed in the number of rodents caught for the first time. This applies both to all the rodents treated jointly and to the separately analysed individuals of the species C. glareolus (Fig. 3A, Fig. 4A). During the phase of capture and removal, however, no constant decrease in the number of animals caught in successive days was recorded (Fig. 3B, Fig. 4B). In view of the absence of regular decrease in the number of individuals caught and removed estimates of numbers 
made by means of the regression method would be incorrect, but such estimates could be made by means of the method proposed.

Calculation was made for the whole trapping period for all the material analysed of the mean period $E_{1, k}(X)$ of manifestation of the presence of all the rodents (Table 3 ) and also separately for C. glareolus (Table 4).

Next, using table 1 , value $p$ was found, and in consequence value $q$ for all the rodents (Table 3 ) and for C. glareolus separately (Table 4). The estimates obtained of the number of all rodents, and also of C. gla-

Table 3.

Estimation of all rodents number.

\begin{tabular}{|l|c|c|c|c|}
\hline \multicolumn{1}{|c|}{ Series } & \multicolumn{2}{c|}{ I } & \multicolumn{2}{c|}{ II } \\
\cline { 2 - 5 } \cline { 5 - 6 } & $\begin{array}{c}\text { Marking } \\
\text { and } \\
\text { release }\end{array}$ & Removal & $\begin{array}{c}\text { Marking } \\
\text { and } \\
\text { release }\end{array}$ & Removal \\
\hline Number of trapping days $(k)$ & 4 & 5 & 5 & 5 \\
$E_{1, k}(X)$ & 1.7108 & 1.2897 & 1.0442 & 1.6930 \\
$p$ & $<0.05$ & 0.30 & 0.40 & 0.15 \\
$N$ & $>447$ & 129 & 123 & 182 \\
\hline
\end{tabular}

Table 4.

Estimated number of C. glareolus.

\begin{tabular}{|l|c|c|c|c|}
\hline \multicolumn{1}{|c|}{ Series } & \multicolumn{2}{|c|}{ I } & \multicolumn{2}{c|}{ II } \\
\cline { 2 - 5 } & $\begin{array}{c}\text { Marking } \\
\text { and } \\
\text { release }\end{array}$ & Removal & $\begin{array}{c}\text { Marking } \\
\text { and } \\
\text { release }\end{array}$ & Removal \\
\hline Number of trapping days $(k)$ & 4 & 5 & 5 & 5 \\
$E_{1, k}(X)$ & 1.6610 & 1.2836 & 1.1923 & 1.6885 \\
$p$ & $<0.05$ & 0.30 & 0.35 & 0.15 \\
$N$ & $>318$ & 81 & 88 & 110 \\
\hline
\end{tabular}

reolus, during the first series of captures from the marking and releasing phase and also from the phase of capture and removal, differ greatly (Table 3 and 4 ).

In the second series of captures the estimates of the number of rodents are similar for $C$. glareolus (Table 4), but we observe a slight surplus for the phase of capture and removal in relation to the phase of marking and releasing in the analysis of all the rodents (Table 3). Analysis was next made of whether probability of capture $(p)$ undergoes variations during the course of trapping. When analysing all ro- 
dents for the mark and release phase of the first series $p<0.05$, for the first three days of the capture and removal phase $p=0.3$ and for the last three days $p=0.2$.

For the marking phase of the second series of captures $p=0.4$ and for the first three days of the capture and removal phase $p=0.2$, and for the last three days $p=0.2$.

Analysing probability of capture separately for $C$. glareolus we obtain for the marking phase of the first series $p<0.05$, for the first three days of capture and removal $p=0.25$, and last three days $p=0.45$. In the second series we obtain respectively $p=0.35, p=0.067, p=0.35$.

The reason for the above variations in probability of capture may be: (a) different rate of entry of animals into the trapping area or (b) occurrence of groups of animals with different degrees of trappability. The decision as to which of the above two suggestions explains the variations observed in probability of capture can only be made on the basis of additional material, e.g. by carrying out trapping in an enclosed area or using stained bait which could be distinguished in the alimentry tract of animals etc. It is thus impossible to decide in the present study which of the above hypotheses, or perhaps both, explain the variations observed in $p$.

It must be emphasised that even in the case when we observe the same probability of capture in two periods it cannot be concluded that the estimates of numbers are similar. Estimate of numbers depends on the ratio of number of individuals captured to probability of capture. As a result, when we have the same $p$ for two periods, but the number of individuals captured varies disproportionately, we also obtain different estimates of numbers.

\section{DISCUSSION}

The method of estimating the number of rodents proposed by $\mathrm{Ha}$ ne (1949) and later used by Grodziński, Pucek \& Ryszkowski (1966), can be applied only to those cases in which we observe a regular decrease in the number of animals caught in consecutive days of capture and removal. This takes place when the following premises are met: probability of capture of all the animals present is uniform; there is no change of population size during the trapping period. In cases in which no regular decrease during capture and removal of the rodents is observed it is impossible to carry out estimates of numbers, e.g. for captures of Micromys minutus ( $\mathrm{P}$ a 11 as, 1778) described by Grodziński, et al. (1966). When increase in the number of rodents caught is observed during the last days of captures, 
calculations were made taking only the data from the first days into consideration, as there was a regular decrease in the number of individuals caught. On this account sthe choice of number of days for which regression was calculated is then to a certain extent subjective and arbitrary " (cf. Grod ziń s k i, et al., 1966).

The method proposed for estimating numbers is free from the restrictions imposed by $\mathrm{H}$ a y $\mathrm{n}$ e's method (1949). It is analogical to the proposals put forward by Moran (1951) and $\mathrm{Zippin}$ (1956). M o r a n (1951) presented a method for obtaining maximum likelihood estimates of populationt size from the results of a series of trappings in which the trapped animals are removed from the population. $\mathrm{Z}$ i ppin (1956) described a rapid graphical procedure for obtaining maximum likelihood estimates of population size from removal method data on the basis of analysis of total trapping period.

The proposed method of calculations permits of making a more accurate estimate of population size by analysing estimates of numbers for different periods (e. g. estimate of numbers for the first three days and last three days of the period analysed).

\section{REFERENCES}

1. Grodziński W., Pucek Z. \& Ryszkowski L., 1966: Estimation of rodent numbers by means of prebaiting and intensive removal. Acta theriol., $11,10: 297-314$.

2. Hay ne D. W., 1949: Two methods for estimating population from trapping records. J. Mamm., 30: 399-411.

3. Moran P. A. P., 1951: A mathematical theory of animals trapping. Biometrika, 38: $307-311$.

4. Traczyk H. \& Traczyk T., 1965: Phytosociological characteritics of the research areas of the Institute of Ecology, Polish Academy of Sciences, at Dziekanów Leśny (Kampinos Forest near Warsaw). Fragm. Flor. Geobot., 11: $547-562$.

5. $\mathrm{Z}$ ippin C., 1956: An evaluation of the removal method of estimating animal populations. Biometrics, 12: 163-189.

Received, May 4, 1968.

Institute of Ecology,

Polish Academy of Sciences,

Warszawa, Nowy Swiat 72. 


\section{Mirosław JANION, Lech RYSZKOWSKI i Teresa WIERZBOWSKA}

\section{OCENA LICZBY GRYZONI PRZY ZMIENNYM PRAWDOPODOBIEŃSTWIE WYEOWU}

\section{Streszczenie}

Opracowano metodę obliczeń pozwalającą na ocenę liczebności gryzoni w przypadku, gdy zmiany liczby osobników wyłowionych w kolejnych dniach połowu uniemożliwiają stosowanie metody regresji prostoliniowej. Proponowana metoda obliczeń polega na ocenie przeciętnego prawdopodobieństwa złowienia gryzoni poprzez wykorzystanie geometrycznego rozkładu warunkowego liczby dni upływających od chwili nastawienia pułapek do momentu ujawnienia przez osobniki swojej obecności (wzory 4, 5, 6). Wyliczone przeciętne prawdopodobieństwo złowienia $p$ pozwala na obliczenie przeciętnego prawdopodobieństwa nie złowienia $q$ ponieważ $1-p=q$. Mając wartość $q$ oraz całkowitą liczbę złowionych zwierząt w trakcie wylowu na podstawie wzoru (8) szacujemy liczbę zwierząt obecnych w tym okresie.

Zastosowanie rozkładów warunkowych pozwala na wyliczenie zmian łowności w trakcie połowów. Np. można ocenić przeciętne prawdopodobieństwo złowienia na podstawie danych $\mathrm{z}$ pierwszych dni wyłowu i porównać je z prawdopodobieństwem złowienia obliczonym na podstawie danych uzyskanych $\mathrm{z}$ ostatnich trzech dni wyłowu (wzory $9,10,11$ ).

Zaproponowana metoda oceny liczby gryzoni może zostać również zastosowana w przypadku połowów gryzoni w pułapki żywolowne, gdy osobniki są znakowane i wypuszczane w miejscu złowienia. W tym przypadku do obliczeń zostają wykorzystane tylko pierwsze złowienia osobników.

Tabele 1 i 2 pozwalają na uzyskanie potrzebnych do obliczeń parametrów bez konieczności ich obliczanie przy pomocy podanych wzorów. Proponowaną metodę oceny liczebności zastosowano do wyników uzyskanych w dwóch seriach połowów. Każda seria składała się z dwóch faz. W fazie pierwszej złowione w żywołowne pułapki gryzonie znakowano indywidualnie i wypuszczano w miejscu złowienia. W drugiej fazie wszystkie złowione zwierzęta usuwano z miejsca złowienia.

Liczby złowionych po raz pierwszy gryzoni w kolejnych dniach pierwszej fazy jak i kolejne liczby złowionych gryzoni w fazie wyłowu przedstawiono na ryc. 1, 2, 3, 4. Uzyskane oceny liczebności gryzoni podano w Tabelach 3 i 4 .

Ocena liczebności jest funkcją prawdopodobieństwa złowienia oraz liczby osobników złowionych w analizowanym okresie czasu. Dlatego też jeżeli dla dwóch okresów uzyskano to samo prawdopodobieństwo złowienia to nie oznacza to, że oceny liczebności będą identyczne. 

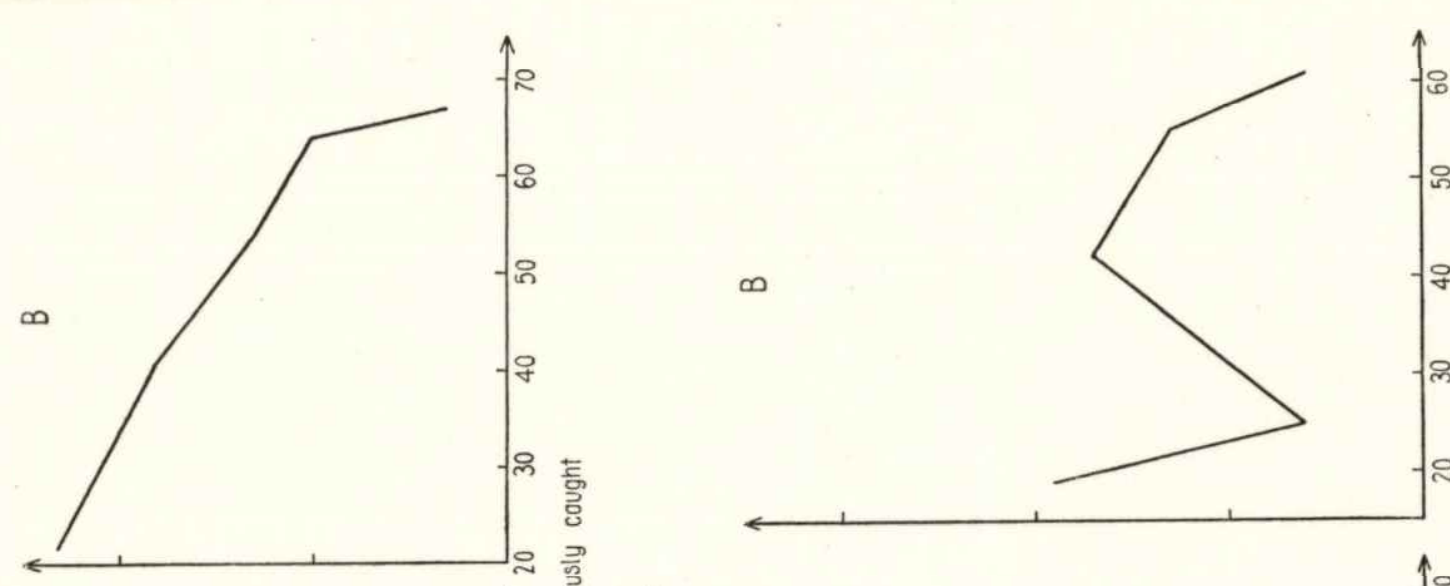

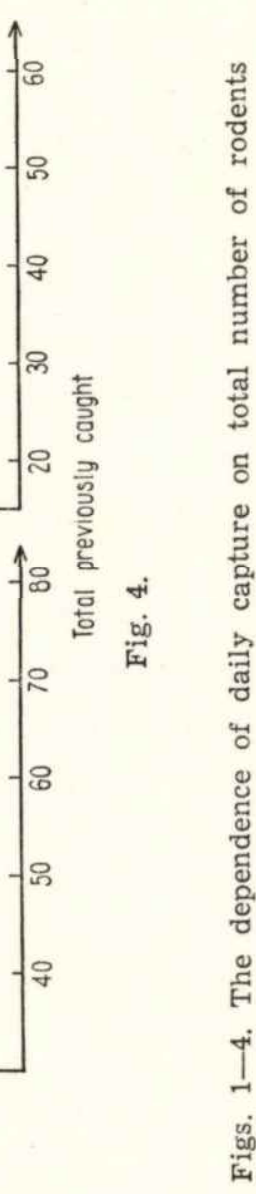
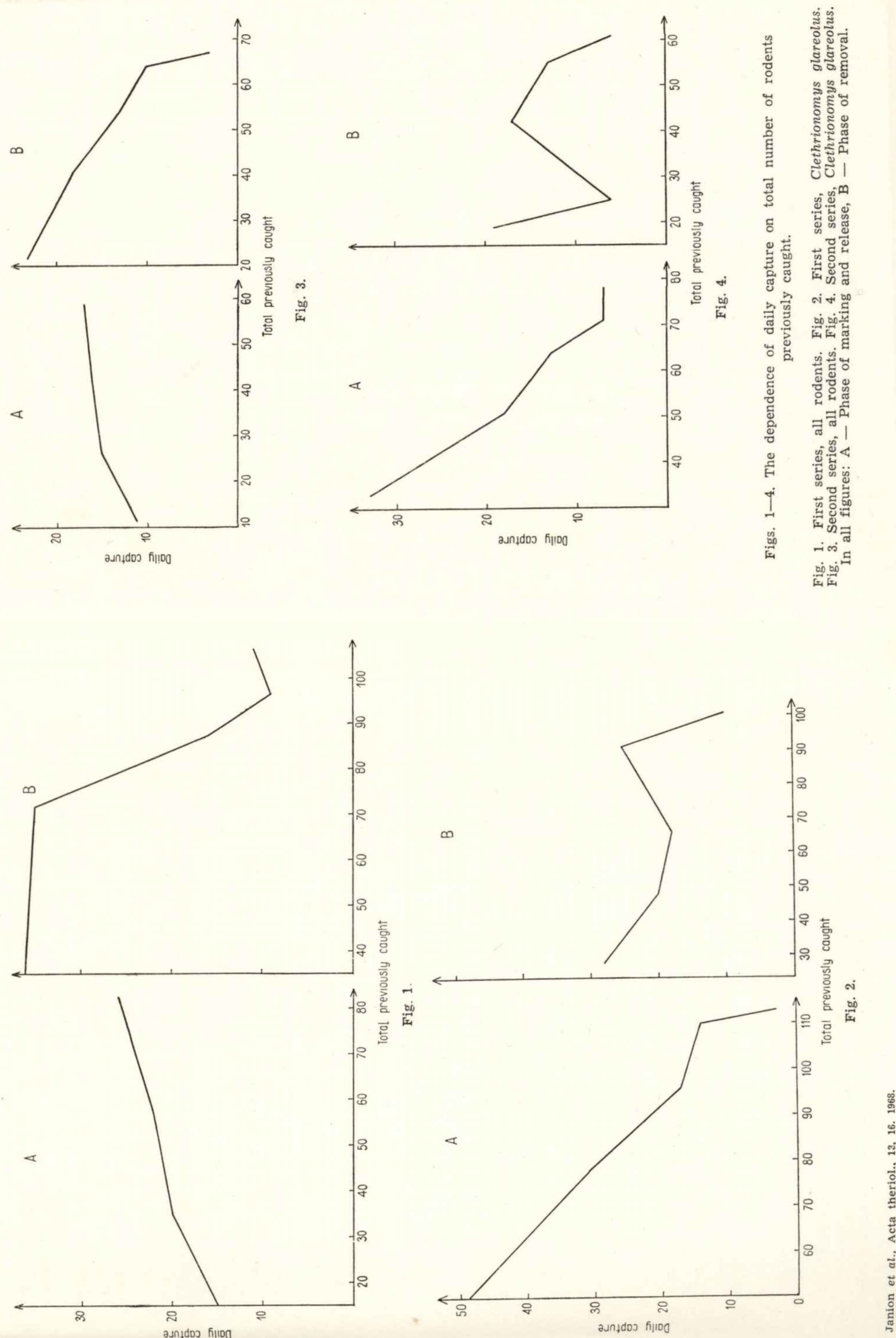